\title{
sciendo
}

DOI: $10.2478 /$ rjti-2018-0005

ROMANIAN JOURNAL

OF TRANSPORT INFRASTRUCTURE

\section{ROLE OF CPEC IN DEVELOPMENT OF TRADE, TRANSPORT AND ECONOMY OF PAKISTAN}

\author{
Ashfaq U. Rehman, Assistant Professor at the Department of Political Science, Women \\ University Swabi, Pakistan;
}

Azizul Hakim, PhD Scholar at the Department of Sociology, University of Peshawar, Pakistan;

Khalid Khan, Assistant Professor at the Department of Economics, Qilu University of Technology, Changqing China, email: shah_khan884@yahoo.com;

Ihsan Ullah Khan, PhD Scholar at the Department of Sociology, University of Peshawar, Pakistan.

\begin{abstract}
The objectives of the study were to measure the efficiency in trade and transport through China Pakistan Economic Corridor (CPEC) and to ascertain efficiency in trade and economic development through developed transport infrastructures. The present study was conducted in Peshawar, Pakistan. The data was collected from the relevant developing sectors and stakeholders through CPEC including investors of Khyber Pakhtunkhwa Chamber of Commerce and Peshawar Railway Station track employees. Majority of bi-variate analysis through chi-square test result showed that there was a strong and significant association between the project of CPEC and efficiency in trade and transport in terms of economy. Similarly, a strong and significant association was found between the development of transport routes through CPEC and smooth transportation of goods and services. Furthermore, a strong and significant association was found between CPEC project and improvement in travelling potential. Similarly, a significant association was found between development in transport infrastructure and fastness and reliability in business travelling. In the same way, a significant association was found between CPEC and increase in the geographical size of the labour market. As in the chain, a strong and significant association was found between the development of transport infrastructures through CPEC and increase in labour force productivity along with an increase in the range of choice of individual and firms. This could come true that CPEC as a project would ensure smooth efficiency transportation of trade goods and services in terms of reducing time distance and cost. CPEC as a project should not be only limited to economic activities, rather it should contribute to the overall socio-economic development of the region.
\end{abstract}

Keywords: CPEC, Efficiency, Transport, Trade, Governance and Economy 


\section{INTRODUCTION}

The physical infrastructure in the form of road and train plays an important role in the development of trade and economic growth. The undeniable importance of the physical infrastructure is no exception for China and Pakistan, which are enjoying a greater than the mountains and deeper than ocean relationship [1]. Over the years, China has played a significant role in the social, economic and financial development of Pakistan. To further strengthen the bilateral ties, China has initiated the China Pakistan Economic Corridor (CPEC), which will help in the economic development of both countries. It is a game changer project and a win-win situation for both countries and will bring economic revolution in the whole region [2]. The project will cause a direct and indirect impact on GDP through the greater inflow of foreign investment. It will overcome the energy shortage in the country. The uninterrupted supply of electricity will have a positive impact on the economic activities and attract the foreign investment. The CPEC project will also meet the energy needs of China. It will develop China's western less developed regions and also improve Pakistan's economy. Furthermore, it is expected to be advantageous to the masses in South Asia, thus supporting regional stability and integration [3].It will create the trade opportunities, boost up the economic condition and trade of Pakistan. The CPEC project will help Pakistan in balancing the unfavourable trade balance with China and trade with neighbouring countries will increase in the future [4].

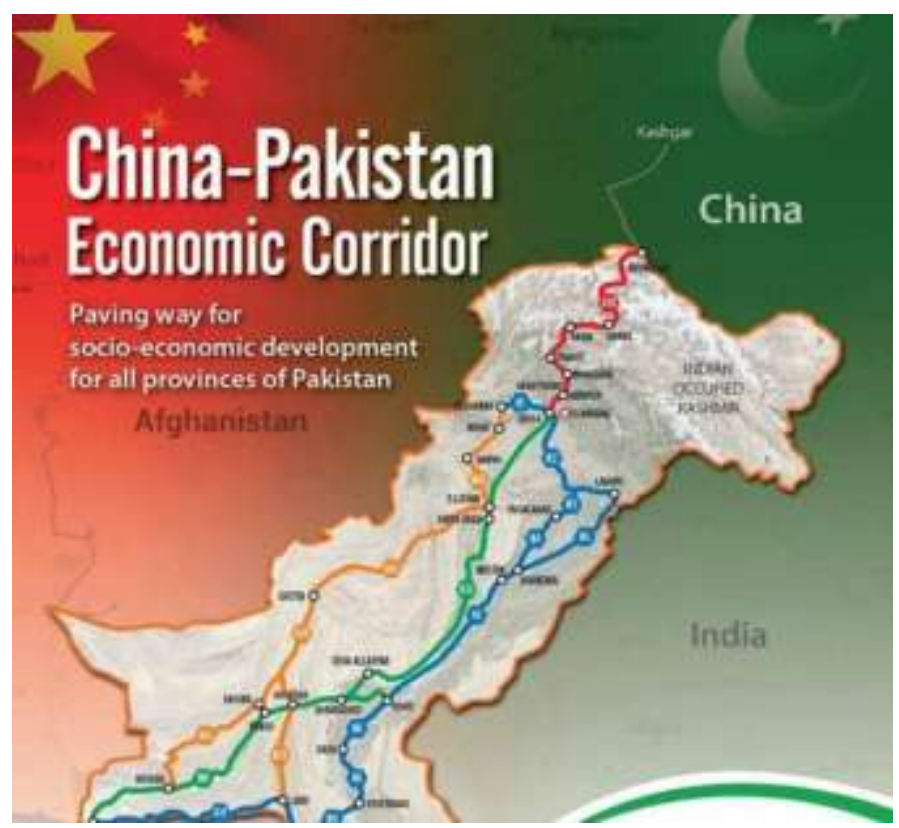

Source: Pakistan Observer: CPEC and India's Growing Nervousness, https://pakobserver.net/cpec-and-indias-growing-nervousness-2/ 
As shown in the map [5], CPEC is an inclusive development program that comprises the linking of Gwadar Port to China's North-Western areas of Xinxiang through highways, optical fibres, railway tracks; and oil and gas pipelines. Its main physical infrastructure is to construct a 27-hundred-kilometre highway from Kashgar to Gwadar through Khunjerab. Besides, railway contracts for freight trains between Gwadar and Khunjerab will be established and will have the possibility of connectivity with Afghanistan, India and Iran. The program will commence the restoration of an extension of the Karakorum highway that links Xinxiang with Pakistan northern areas Gilgit-Baltistan and Khyber Pakhtunkhwa. The physical linkage between China and Pakistan through the CPEC provides an opportunity to establish numerous economic zones along with the corridors. An energy planning working group of the CPEC has also been established and has initiated a fast-track implementation of power projects associated with the CPEC. These are of 21,690 MW project of power productions which will be ongoing with the support of China under the CPEC policy. The CPEC is a tremendous project that will initiate the building of highways and railway links running through most of Pakistan. These will start from Gwadar in Baluchistan and end in Kashgar in western China while passing through different economic zones of Baluchistan, Khyber Pakhtunkhwa, Sindh, Punjab provinces and Gilgit-Baltistan in northern Pakistan to extend the Khunjerab Pass and outside China [6].

Besides others plans in CPEC project, the improvement of transport routes in the form of roads, railway tracks and ports will ensure efficiency in transport and trade. Among the other developments are transported routes in CPEC including Karakorum Highway and Railway track from Peshawar to Karachi. It also includes industrial units and the establishment of Special Economic Zones (SEZ) along these routes which are a source of a quantum leap in the socio-economic setting of the local masses. One of the major aims of this study was to what extent the people of Pakistan will be executing the CPEC successfully. In addition, it is also worthy to know that how much will it develop the human capital, hosting socio-economic profile. The results indicate that development of transport infrastructures through CPEC will increase labour force productivity; ensure a smooth and efficient transportation of trade goods and services along with reducing time, distance and cost.

The paper has been organized in a systematic manner. Section-1 explains the detailed introduction and relevant literature review. Section-2 describes the materials and methods used for data collection through scientific tools. Section3 evaluates the results, critical discussion of the analysed data is made. Section-4 
ROMANIAN JOURNAL

OF TRANSPORT INFRASTRUCTURE

Ashfaq U. Rehman, Azizul Hakim, Khalid Khan, Ihsan Ullah Khan

Role of CPEC in development of trade, transport and economy of Pakistan

concludes the paper with a compact analysis and key suggestions for the policymakers.

\section{REVIEW OF LITERATURE}

The development of transport infrastructures provides accessibility and opportunities to all people, certainly to those who do not have access to motor vehicles. It will also provide a substitute to decrease pressure on the transport infrastructures. Provision of robust enthusiasm for using public transport services is another conspicuous feature of developed transport infrastructure. Access is the opportunity based on closeness to services and cost. Accessibility is the suitability of public transport to get individuals or goods from the system's entry point to their exit location in their reasonable time span. The accessibility also encompasses the operational function of the system for the regional travel [7].

Similarly, there are other dimensions of developing transport services through the corridor. Among these features, one is the mono-functional use of the city. This sort of system is present in South African cities, which is more attractive and competitive. South African cities land brings more economic efficiency and productivity which further lead to the efficient use of infrastructure and resources and increase economic relationships. The joined use of land increases accessibility and discourages urban spreading while the prevailing and new urban nodes bring a different type of development. It is generally significant for low-income areas the previously separated black group areas to use transport corridor to generate activity of backbones that would improve the economic potential of the previously disadvantaged areas [8].

Likewise, the development of transport infrastructure increases the efficiency of trade of a company or industry in that region. The developed transport infrastructure improves reliability and accessibility in manufacturing and delivery of products. When a company has more access to a market that generates more business opportunities and increases competition and further lead to more income generation [9].It has been academically and empirically pointed out the great amount of less developing countries blocked-in economy and their access to world economy depends on trade corridor. The consequences express that the landlocked economy is not affected by freight services but also unpredictability of transport time [10]. For the efficiency of trade not only port efficiency, customs environment, controlling environment but services sectors infrastructure improvement is also necessary for trade efficiency. The development of transport infrastructures increases in efficiency of trade and 
ROMANIAN JOURNAL

OF TRANSPORT INFRASTRUCTURE

Ashfaq U. Rehman, Azizul Hakim, Khalid Khan, Ihsan Ullah Khan

Role of CPEC in development of trade, transport and economy of Pakistan

transport not only within the state and provinces but also at the international level among the states [11].

Similarly, internationally, the prerequisite improvement in infrastructure expedites trade cooperation between South Asia, Afghanistan and Pakistan. From the total fund of the National Trade Corridor which is $\$ 9$ billion, $\$ 5$ billion is spent on the highways and 1.5 billion on the railway track upgrading and extending to Afghanistan, while the remaining for the upgrading of two-sided trade. Trade zones will also be established along the motorways to decrease the cost of business and Pakistani goods make more competitive globally in the market [12]. It has been illuminated virtuous circle between growth infrastructures investment trade extension and regional integration [13]. It has been reiterated that robust investment in infrastructure would expedite achieving economic growth and ultimately poverty mitigation [14]. Liu and $\mathrm{Hu}$ [15] recommended eight aspects for gauging the long-term development of metro transport infrastructure including consultation with planning, system scheming, operation management, consumer satisfaction, post-evaluation on the environmental effects, economic analysis and degree of public participation.

The research related the North Eastern Corridors of Taiwan indicates that sustainable development can achieve through efficiency regarding in these sectors terminal operation cost, traffic accident cost, transit time between $\mathrm{O}$ and $\mathrm{D}$ and transport cost [16].The performance of metro infrastructure scheme fluctuates from country to country and city to city due to reasons of diverse mechanical and executive skills. From the instance of Tokyo Metro, London Underground Transport, Paris Metro and MTR of Hong Kong are all good examples. Both Hong Kong and New York have a well-established rail scheme considered by extensive network structure and high transit ridership [17].

The transport global infrastructure report, 2010, shows that Pakistan is on 101 out of 133 countries in term of good road infrastructure, the supply of quality electricity and telecommunication lines. Pakistan got 3.06 out of 7 and 88 scores out of 133 countries [12]. Pagliara \& Papa [18] express the association between utility and efficiency of urban rail transit system and land proper use in a specific city. The researchers reiterated on better land use to achieve metro efficiency. Researchers have conducted thorough research on the transport system from the perspective of sustainable development. This includes economic benefits, social advantages, and eco-efficiency and execution performance. This will gauge the performance of four sub-models i.e., the level of harmony and sustainability, development positions. Su et al.,[19] gauged the efficiency through eight aspects which include economic, social, ecological, policy, management, city, technology and traffic. 


\section{MATERIALS AND METHODS}

\subsection{The universe of the Study}

This portion dealt with the universe of study, data collection, data analysis, sampling etc. The present study has been carried out in Khyber Pakhtunkhwa to assess the social impact of China Pakistan Economic Corridor (CPEC) over the people of Pakistan. It was intended to be a perceptionof nature and has analysed the perceived social impact of CPEC. The study has been designed to assess trade, transport development through the establishment of CPEC. Appropriate statistical tools have been carefully selected and applied to ensure the most reliable inferences within the review of the interaction between dependent and independent variables.

\subsection{Conceptual Framework}

Operationalization of data has been carried out by keeping into considerations the conceptual framework shown in Table 1.

Table 1. Conceptual framework

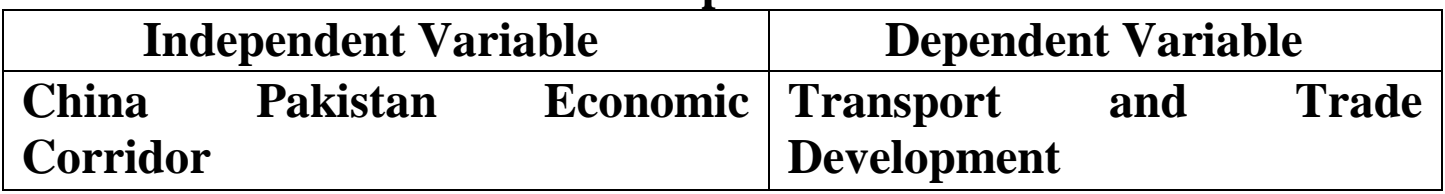

\subsection{Sampling and sample design}

The sample is a representative subgroup of the population while, sampling is the process of selecting enough number of elements from the population, through which results are generalized to the whole population. The total respondent's population of the three sectors, the total investors in the chamber of commerce of Khyber Pakhtunkhwa, Railway employees working in the Peshawar, and the Peshawar university social science faculty members. The total population of the three sectors was 2,114 members. A sample size of 308 respondents has been taken for an in-depth interview as this number was taken as per Sekaran table [20] mentioned population and sample size determination. Furthermore, the sampled respondents were divided into different stratum according to the relevant population size as shown in the Table 2. 
ROMANIAN JOURNAL

OF TRANSPORT INFRASTRUCTURE

Ashfaq U. Rehman, Azizul Hakim, Khalid Khan, Ihsan Ullah Khan

Role of CPEC in development of trade, transport and economy of Pakistan

Table 2. Sampled respondents

\begin{tabular}{|l|l|l|l|}
\hline \multicolumn{2}{|l|}{ Population Size } & \multicolumn{2}{l|}{ Sample Size } \\
\hline $\begin{array}{l}\text { Chamber of commerce } \\
\text { investors }\end{array}$ & 569 & N1th=n/Nxn1th & $308 / 2114 \times 569=83$ \\
\hline Railway employees & 1504 & N1th=n/Nxn2th & $308 / 2114 \times 1504=219$ \\
\hline $\begin{array}{l}\text { Social science } \\
\text { faculties members }\end{array}$ & 41 & N1th=n/Nxn3th & $308 / 2114 \times 41=6$ \\
\hline Total population & 2114 & Total sample size & 308 \\
\hline
\end{tabular}

\subsection{Data Collection}

For collecting primary data, a well thought out and comprehensive questionnaire has been designed to measure each variable of interest encompassing all the basic aspects of the study. The questionnaire consisted of three major sections i.e. background variables, the impact of CPEC (dependent variable), and trade and transport efficiency, social inclusion, local investors investment, CPEC establishment, as independent variables. The questionnaire has been planned on a Likert scale with three categories of response ranging from strongly agree to strongly disagree. Prior to embarking on the collection of data, the questionnaire has been pre-tested [21].

\subsection{Data Analysis}

The data collected through the questionnaire was systematically analysed and was used in combination with statistical analysis through software Statistical Package for Social Sciences (SPSS version 20). SPSS has been used for both Uni-variate and Bi-variate analysis for data presentation and analysis. Moreover, the distribution analysis has been also applied to both the univariate and bivariate data tables. After the data collection, the database was analysed through uni-variate or simple percentage, frequency distribution and distribution of data to check the layout of the data. The bivariate analysis was carried out to measure the level of association and the relationships between independent and dependent variables through chi-square test applications. The chi-square test has been used to test the association between dependent and independent variables. Following a statistical technique has been adapted to calculate the chi-square. 
Where;

$$
\chi^{2}=\sum_{i=1}^{c} \sum_{j=1}^{r} \frac{\left(O_{i j}-e_{i j}\right)^{2}}{e_{i j}}
$$

$\left(\chi^{2}\right)=$ Symbol of Chi-Square

Df $=(\mathrm{r}-1)$ and (c-1) degree of freedom

Oij $=$ Observed frequency of columns and rows

Eij = Expected frequency of columns and rows (ith is for rows and jth is for columns)

\section{RESULTS AND DISCUSSIONS}

The data collected for this study has been analysed mainly through Univariate, Bi-variate and distribution analysis. The systematically analysed data has been discussed in detail and resulted have been properly elaborated as follows:

\subsection{UNI-VARIATE ANALYSIS}

The univariate analysis is for finding the percentages and frequencies of respondents views regarding the development in trade and transport through the establishment of China Pakistan Economic Corridor (CPEC).

Among the socio-economic development through CPEC, trade and transport efficiency is one of them. CPEC will bring efficiency in trade and transport in terms of economy, smoothness in the transportation of goods, reduction in travel time of goods, increase in frequently travelling potential, will reduce cost and barriers to travel. It will also increase the geographical size of the labour market and more inclusion of tourists. It has been illustrated in Table 3.

Table 3. Frequency Distribution and Proportion of Trade and Transport Development

\begin{tabular}{|c|c|c|c|c|c|c|c|c|c|c|c|c|c|c|}
\hline \multirow{3}{*}{ Attributes } & \multicolumn{7}{|c|}{ Trade and Transport Development } & \multirow{3}{*}{$\begin{array}{l}\underset{\mathbb{X}}{\mathbb{X}} \\
\underset{\Sigma}{\mathbb{E}}\end{array}$} & \multirow[b]{3}{*}{$\begin{array}{l}\text { (6) } \\
\text { के }\end{array}$} & \multirow[b]{3}{*}{$\begin{array}{l}0 \\
+ \\
x\end{array}$} & \multirow[b]{3}{*}{$\begin{array}{l}0 \\
1 \dot{x}\end{array}$} & \multicolumn{3}{|c|}{ \% Dev. } \\
\hline & \multicolumn{2}{|c|}{ S.A } & \multicolumn{2}{|c|}{ A } & \multicolumn{2}{|c|}{$\mathbf{N}$} & \multirow{2}{*}{$\begin{array}{c}\text { Tot } \\
\text { al }\end{array}$} & & & & & $\bar{d}$ & $\mathfrak{d}$ & d \\
\hline & o.v & $\% \mathrm{~V}$ & o.v & $\% \mathrm{~V}$ & o.v & $\% \mathrm{~V}$ & & & & & & Е & $\begin{array}{l}\text { E } \\
\text { हू }\end{array}$ & ڤ్ \\
\hline
\end{tabular}




\section{ROMANIAN JOURNAL OF TRANSPORT INFRASTRUCTURE}

Ashfaq U. Rehman, Azizul Hakim, Khalid Khan, Ihsan Ullah Khan

Role of CPEC in development of trade, transport and economy of Pakistan

\begin{tabular}{|c|c|c|c|c|c|c|c|c|c|c|c|c|c|c|}
\hline $\begin{array}{l}\text { CPEC is a source of } \\
\text { trade and transport } \\
\text { efficiency in the form } \\
\text { of accessibility and } \\
\text { reliability in terms of } \\
\text { economy }\end{array}$ & 231 & 75 & 77 & 25 & & & 308 & 154 & 109 & 263 & 45 & 13 & 5 & 0 \\
\hline $\begin{array}{l}\text { CPEC infrastructure } \\
\text { will improve smooth } \\
\text { transportation of goods }\end{array}$ & 123 & 39.9 & 183 & 59.4 & 2 & 0.6 & 308 & 123 & 92 & 215 & 31 & 7 & 12 & 1 \\
\hline $\begin{array}{l}\text { CPEC reduces travel } \\
\text { time of goods and } \\
\text { passengers }\end{array}$ & 75 & 24.4 & 180 & 58.4 & 53 & 17.2 & 308 & 75 & 68 & 143 & 7 & 4 & 12 & 33 \\
\hline $\begin{array}{l}\text { CPEC will increase the } \\
\text { potential to travel } \\
\text { frequently }\end{array}$ & 203 & 65.9 & 104 & 33.8 & 1 & 0.3 & 308 & 104 & 101 & 205 & 3 & 12 & 7 & 1 \\
\hline $\begin{array}{l}\text { CPEC will reduce cost } \\
\text { of travel by decreasing } \\
\text { barriers to travel } \\
\text { \&transport }\end{array}$ & 75 & 24.4 & 233 & 75.6 & & & 308 & 154 & 112 & 266 & 42 & 4 & 15 & 0 \\
\hline $\begin{array}{l}\text { CPEC will develop } \\
\text { business and makes } \\
\text { travel faster }\end{array}$ & 203 & 65.9 & 105 & 34.1 & & & 308 & 154 & 69 & 223 & 85 & 12 & 7 & 0 \\
\hline $\begin{array}{l}\text { CPEC will increase in } \\
\text { labour force } \\
\text { productivity, }\end{array}$ & 255 & 73.1 & 83 & 26.9 & & & 308 & 169 & 122 & 291 & 47 & 15 & 5 & 0 \\
\hline $\begin{array}{l}\text { CPEC will increase the } \\
\text { geographical size of the } \\
\text { labour market }\end{array}$ & 168 & 54.5 & 140 & 45.5 & & & 308 & 154 & 20 & 174 & 134 & 10 & 9 & 0 \\
\hline $\begin{array}{l}\text { CPEC will increase the } \\
\text { geographical size of the } \\
\text { labour market }\end{array}$ & 168 & 54.5 & 140 & 45.5 & & & 308 & 154 & 20 & 174 & 134 & 10 & 9 & 0 \\
\hline $\begin{array}{l}\text { An increase in } \\
\text { accessibility leads to an } \\
\text { increase in travel } \\
\text { distance, then the range } \\
\text { of choice of individual } \\
\text { and firms will increase }\end{array}$ & 125 & 40.6 & 182 & 59.1 & 1 & 0.3 & 308 & 125 & 93 & 218 & 32 & 7 & 12 & 1 \\
\hline $\begin{array}{l}\text { CPEC will improve the } \\
\text { inclusion of tourists in } \\
\text { local economy }\end{array}$ & 102 & 33.1 & 101 & 32.8 & 104 & 33.8 & 308 & 102 & 2 & 104 & 100 & 6 & 7 & 65 \\
\hline
\end{tabular}

Source: Field Survey Conducted in 2016.

Table 3 numerically evaluates the perceptions of the masses about trade and transport efficiency through CPEC. Efficiency increases accessibility and reliability in terms of trade and economy. Out of total 308(100\%), the respondents which had strong perceptions were 231(75\%), while the remaining $77(25 \%)$ would only agree that (yes) implementation of CPEC will bring efficiency in trade and transport. It has been supported by researchers through their own research that development of transport infrastructures increases the efficiency in trade of a company or industry in that region. It also improves 
ROMANIAN JOURNAL

OF TRANSPORT INFRASTRUCTURE

Ashfaq U. Rehman, Azizul Hakim, Khalid Khan, Ihsan Ullah Khan

Role of CPEC in development of trade, transport and economy of Pakistan

reliability and accessibility in manufacturing and delivery of products. When a company has more access to a market, it generates more business opportunities and increases competition and further leads to more income generation [9]. The results are in line with the view of Ismail and Mahyideen [22] who suggests that infrastructure plays an important role in trade development.

The development of physical transport infrastructures makes the transportation of goods smooth. 123(39.9\%) of the respondents perceived, while the remaining 183(59.4\%) also agreed and 02(0.6\%) had neutral approaches about the role of good infrastructure in the smoothness of goods. Most of the $75(24.4 \%)$ respondents also strongly perceived that CPEC will reduce the travel time of goods and passengers, while the remaining $180(58.4 \%)$ of the respondents also agreed and 53(17.2\%) had a neutral approach that CPEC will reduce the time travel of goods. Similarly, 203(65.9\%) of the respondents strongly viewed, 104(33.8\%) of the respondents also viewed and 01(0.3\%) had neutral approach respectively that CPEC will improve travel potential and make him frequent.

The respondents $74(24.5 \%)$ had strong perceptions, 233(75.6\%) of the respondents also viewed that the transport infrastructures in CPEC will reduce cost and barriers to travel. Other respondents which were 203(65.9\%) strongly viewed that and the remaining 105(34.1\%) of the respondents also perceived that CPEC transport routes will make transport fast and reliable.

CPEC will increase labour force productivities because it reduces travel time due to improved accessibility. As a result, this time is being used in productive activities. Out of total 308(100\%) of the respondents, 225(73.1\%) of the respondents strongly agreed, $83(26.9 \%)$ only agreed with this statement that CPEC brings efficient labour force productivities. Besides this, CPEC will increase the geographical size of the labour market. 168(54.5\%) of the respondents strongly viewed, while $140(45.5 \%)$ of the respondents viewed that CPEC will increase the geographical size of the labour market.

Likewise, increase in accessibility will increase travel distance than the range of choice of individual and firm will be increased. Out of total 308(100\%) respondents, $125(40.6 \%)$ strongly agreed, $182(59.1 \%)$ only agreed and $01(0.3 \%)$ had a neutral view about this statement. Similarly, CPEC has the potential for more attraction for and the inclusion of tourists. Out of 308(100\%) respondents, $102(33.1 \%)$ of the respondents strongly agreed, $101(32.1 \%)$ only agreed, $104(33.8 \%)$ had neutral views and $01(0.3 \%)$ disagreed with this view. 
ROMANIAN JOURNAL

OF TRANSPORT INFRASTRUCTURE

Ashfaq U. Rehman, Azizul Hakim, Khalid Khan, Ihsan Ullah Khan

Role of CPEC in development of trade, transport and economy of Pakistan

\subsection{BI-VARIATE ANALYSIS}

The $\mathrm{Bi}$-Variate analysis is used for finding the association between the dependent variable (Trade and transport development) and Independent variable as China Pakistan Economic Corridor (CPEC).

CPEC as a mega project consists of roads, railways tracks, ports, optical fibre lines, hydro and coal-based power projects and special economic zones (SEZ). The development of transport infrastructures in the form of roads and railway tracks ensures efficiency in trade and transport. The construction of Karakorum Highway (KKHW), Peshawar to Karachi railway track and establishment of special economic zones (SEZ) in Khyber Pakhtunkhwa (KP) will increase accessibility and reliability of trade and transport in terms of economy. CPEC will ensure the smooth transportation of goods from GilgitBaltistan and Kohistan like dry fruit, potato and mobilization of other locally manufactured and natural goods. The development of transport infrastructure will reduce the cost of the transported goods lay reducing the minimum all kinds of road hazards.

\section{Table 4. Association between CPEC and Trade and Transport Development}

\begin{tabular}{|c|c|c|c|c|c|c|c|c|c|c|c|c|c|c|}
\hline \multirow{3}{*}{ Attributes } & \multirow{3}{*}{ 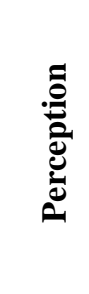 } & \multicolumn{6}{|c|}{ Trade and Transport Efficiency } & \multirow{3}{*}{ 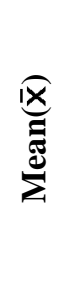 } & \multirow{3}{*}{ के } & \multirow{3}{*}{$\begin{array}{c}0 \\
\stackrel{1}{+}\end{array}$} & \multirow{3}{*}{ 茫 } & \multicolumn{2}{|c|}{$\begin{array}{c}\% \\
\text { Deviation }\end{array}$} & \multirow{3}{*}{$\begin{array}{l}\text { Chi } \\
\text { Square } \\
\text { and } \\
\text { P value }\end{array}$} \\
\hline & & \multicolumn{2}{|c|}{ S.A } & \multicolumn{2}{|c|}{$\mathbf{A}$} & \multicolumn{2}{|c|}{ Total } & & & & & $\bar{d}$ & $\stackrel{1}{d}$ & \\
\hline & & $\begin{array}{l}\text { O. } \\
\text { V }\end{array}$ & $\% \mathrm{~V}$ & $\begin{array}{l}\text { O. } \\
\text { V }\end{array}$ & $\% \mathrm{~V}$ & $\begin{array}{l}\text { O. } \\
\text { V }\end{array}$ & $\% \mathrm{~V}$ & & & & & हై & हूँ & \\
\hline \multirow{4}{*}{$\begin{array}{l}\text { CPEC is a source } \\
\text { of trade and } \\
\text { transport } \\
\text { efficiency in } \\
\text { term of trade and } \\
\text { economy }\end{array}$} & S. A & 117 & 38 & 114 & 37 & 231 & 75 & 77 & 2 & 79 & 75 & 51 & 49 & \multirow{4}{*}{$\begin{array}{l}\chi^{2}=71.66 \\
\mathrm{P}= \\
(0.000)\end{array}$} \\
\hline & A & 5 & 1.6 & 72 & 23.4 & 77 & 25 & 26 & 47 & 73 & -22 & 6 & 94 & \\
\hline & $\mathrm{N}$ & & & & & & & & & & & & & \\
\hline & Total & 122 & 39.6 & 186 & 60.4 & 308 & 100 & 103 & 45 & 148 & 57 & 40 & 60 & \\
\hline \multirow{4}{*}{$\begin{array}{l}\text { The transport } \\
\text { infrastructures in } \\
\text { CPEC project } \\
\text { will make } \\
\text { smooth } \\
\text { transportation of } \\
\text { goods }\end{array}$} & S.A & 10 & 3.2 & 113 & 36.7 & 123 & 39.9 & 41 & 73 & 114 & -32 & 8 & 92 & \multirow{4}{*}{$\begin{array}{l}\chi^{2}=147.5 \\
6 \\
P=(0.000)\end{array}$} \\
\hline & A & 112 & 36.4 & 71 & 23.1 & 183 & 59.4 & 61 & 29 & 90 & 32 & 61 & 39 & \\
\hline & $\mathrm{N}$ & & & & & & & & & & & & & \\
\hline & Total & 122 & 39.6 & 186 & 60.4 & 308 & 100 & 103 & 45 & 148 & 57 & 40 & 60 & \\
\hline \multirow{4}{*}{$\begin{array}{l}\text { CPEC reduce } \\
\text { travel time of } \\
\text { goods and } \\
\text { passengers }\end{array}$} & S.A & 12 & 3.9 & 63 & 20.5 & 75 & 24.4 & 25 & 36 & 61 & -11 & 16 & 84 & \multirow{4}{*}{$\begin{array}{c}\chi^{2}=125.0 \\
2 \\
\mathrm{P}=(0.000)\end{array}$} \\
\hline & $\mathrm{A}$ & 109 & 35.4 & 71 & 23.1 & 180 & 58.4 & 60 & 27 & 87 & 33 & 61 & 39 & \\
\hline & $\mathrm{N}$ & 1 & 0.3 & 52 & 16.9 & 53 & 17.2 & 18 & 36 & 54 & -18 & 2 & 98 & \\
\hline & Total & 122 & 39.6 & 186 & 60.4 & 308 & 100 & 103 & 45 & 148 & 57 & 40 & 60 & \\
\hline
\end{tabular}




\section{ROMANIAN JOURNAL OF TRANSPORT INFRASTRUCTURE}

Ashfaq U. Rehman, Azizul Hakim, Khalid Khan, Ihsan Ullah Khan

Role of CPEC in development of trade, transport and economy of Pakistan

\begin{tabular}{|c|c|c|c|c|c|c|c|c|c|c|c|c|c|c|}
\hline \multirow{4}{*}{$\begin{array}{l}\text { CPEC transport } \\
\text { infrastructure } \\
\text { will increase } \\
\text { frequently } \\
\text { travelling } \\
\text { potential }\end{array}$} & S.A & 86 & 27.9 & 117 & 38 & 203 & 65.9 & 68 & 22 & 90 & 46 & 42 & 58 & \multirow{4}{*}{$\begin{aligned} \chi^{2} & =43.84 \\
P & =(0.000)\end{aligned}$} \\
\hline & A & 36 & 11.7 & 68 & 22.1 & 104 & 33.8 & 35 & 23 & 57 & 12 & 35 & 65 & \\
\hline & $\mathrm{N}$ & & & 1 & 0.3 & 1 & 0.3 & & & & & & 100 & \\
\hline & Total & 122 & 39.6 & 186 & 60.4 & 308 & 100 & 103 & 45 & 148 & 57 & 40 & 60 & \\
\hline \multirow{4}{*}{$\begin{array}{l}\text { CPEC transport } \\
\text { infrastructure } \\
\text { reduces the cost } \\
\text { of transport and } \\
\text { barrier to } \\
\text { transport/travelli } \\
\text { ng of goods }\end{array}$} & S.A & 12 & 3.9 & 63 & 20.5 & 75 & 24.4 & 25 & 36 & 61 & -11 & 16 & 84 & \multirow{4}{*}{$\begin{array}{l}\chi^{2}=56.22 \\
P=(0.000)\end{array}$} \\
\hline & $\mathrm{A}$ & 110 & 35.7 & 123 & 39.9 & 233 & 75.6 & 78 & 9 & 87 & 68 & 47 & 53 & \\
\hline & $\mathrm{N}$ & & & & & & & & & & & & & \\
\hline & Total & 122 & 39.6 & 186 & 60.4 & 308 & 100 & 103 & 45 & 148 & 57 & 40 & 60 & \\
\hline \multirow{4}{*}{$\begin{array}{l}\text { CPEC } \\
\text { infrastructure } \\
\text { will make } \\
\text { business goods } \\
\text { exchange fast }\end{array}$} & S.A & 86 & 27.9 & 117 & 38 & 203 & 65.9 & 68 & 22 & 90 & 46 & 42 & 58 & \multirow{4}{*}{$\begin{array}{l}\chi^{2}=39.064 \\
\mathrm{P}=(0.000)\end{array}$} \\
\hline & A & 36 & 11.7 & 69 & 22.4 & 105 & 34.1 & 35 & 23 & 58 & 12 & 34 & 66 & \\
\hline & $\mathrm{N}$ & & & & & & & & & & & & & \\
\hline & Total & 122 & 39.6 & 186 & 60.4 & 308 & 100 & 103 & 45 & 148 & 57 & 40 & 60 & \\
\hline \multirow{4}{*}{$\begin{array}{l}\text { CPEC will } \\
\text { increase labour } \\
\text { force } \\
\text { productivity, } \\
\text { improved } \\
\text { accessibility, } \\
\text { reduce travel } \\
\text { time which could } \\
\text { be used then in } \\
\text { productive } \\
\text { activities }\end{array}$} & S.A & 110 & 35.7 & 117 & 37.3 & 225 & 73.1 & 75 & 5 & 80 & 70 & 49 & 52 & \multirow[b]{4}{*}{$\begin{array}{l}\chi^{2}=105.97 \\
P=(0.000)\end{array}$} \\
\hline & $\mathrm{A}$ & 12 & 3.9 & 71 & 23.1 & 83 & 26.9 & 28 & 42 & 69 & -14 & 14 & 86 & \\
\hline & $\mathrm{N}$ & & & & & & & & & & & & & \\
\hline & Total & 122 & 39.6 & 186 & 60.4 & 308 & 100 & 103 & 45 & 148 & 57 & 40 & 60 & \\
\hline \multirow{4}{*}{$\begin{array}{l}\text { CPEC increases } \\
\text { the geographical } \\
\text { size of the labour } \\
\text { market }\end{array}$} & S.A & 62 & 20.1 & 106 & 34.4 & 168 & 54.5 & 56 & 31 & 87 & 25 & 37 & 63 & \multirow{4}{*}{$\begin{array}{l}\chi^{2}=105.95 \\
P=(0.000)\end{array}$} \\
\hline & A & 60 & 19.5 & 80 & 26 & 140 & 45.5 & 47 & 14 & 61 & 33 & 43 & 57 & \\
\hline & $\mathrm{N}$ & & & & & & & & & & & & & \\
\hline & Total & 122 & 39.6 & 186 & 60.4 & 308 & 100 & 103 & 45 & 148 & 57 & 40 & 60 & \\
\hline \multirow{4}{*}{$\begin{array}{l}\text { Increase in } \\
\text { accessibility } \\
\text { leads to increase } \\
\text { in travel distance } \\
\text { then the range of } \\
\text { choice of } \\
\text { individual and } \\
\text { firm will be } \\
\text { increase }\end{array}$} & S.A & 115 & 37.3 & 10 & 3.5 & 125 & 40.6 & 42 & 74 & 116 & -33 & 92 & 8 & \multirow{4}{*}{$\begin{array}{c}\chi^{2}=53.25 \\
P=(0.000)\end{array}$} \\
\hline & A & 6 & 1.9 & 176 & 57.1 & 182 & 59.1 & 61 & 120 & 181 & -60 & 3 & 97 & \\
\hline & $\mathrm{N}$ & 1 & 0.3 & & & 1 & 0.3 & & & & & 100 & & \\
\hline & Total & 122 & 39.6 & 186 & 60.4 & 308 & 100 & 103 & 45 & 148 & 57 & 40 & 60 & \\
\hline \multirow{4}{*}{$\begin{array}{l}\text { CPEC enhances } \\
\text { the inclusion of } \\
\text { tourists in local } \\
\text { economy }\end{array}$} & S.A & 35 & 11.4 & 67 & 21.8 & 102 & 33.1 & 34 & 23 & 57 & 11 & 34 & 66 & \multirow{4}{*}{$\begin{array}{c}\chi^{2}=77.92 \\
\mathrm{P}=(0.000)\end{array}$} \\
\hline & $\mathrm{A}$ & 87 & 28.2 & 14 & 4.5 & 101 & 32.8 & 34 & 52 & 85 & -18 & 86 & 14 & \\
\hline & $\mathrm{N}$ & & & 104 & 33.8 & 104 & 33.8 & 35 & & & & & 100 & \\
\hline & Total & 122 & 39.6 & 186 & 60.4 & 308 & 100 & 103 & 45 & 148 & 57 & 40 & 60 & \\
\hline
\end{tabular}

Source: Field survey conducted in 2016. 
ROMANIAN JOURNAL

OF TRANSPORT INFRASTRUCTURE

Ashfaq U. Rehman, Azizul Hakim, Khalid Khan, Ihsan Ullah Khan

Role of CPEC in development of trade, transport and economy of Pakistan

Table 4 shows the association between CPEC, trade and transport efficiency. A strongly significant $(\mathrm{P}=0.000)$ association was found between trade and transport efficiency in terms of economy. It reveals from these results that CPEC is one of the great opportunities to improve the economic relationship between China and Pakistan. The smooth and fast transportation would ensure timely transfer of goods from China through CPEC to all over the world. It will certainly boost the ratio of local involvement in trade and business, which is in line with the finding of Dewar [8] that corridor will ensure efficiency in transport and trade in terms of the economy. The CPEC will result in generating backbone activities that would improve the economic potential of the surrounding areas.

Similarly, a strongly significant $(\mathrm{P}=0.000)$ association was found between smooth transportation of goods through efficiency in trade and transport, development of transport infrastructures through CPEC. The development of transport routes in the form of roads and railway tracks will ensure the smooth transportation of local goods. These results support the findings of Arvis [10] who states that efficiency in transport services is pre-requisite for the improvement of trade and economy. In the same way, a strongly significant $(\mathrm{P}=0.000)$ association existed between the development of transport routes through CPEC and reduction in time for travelling of goods and passengers. The reduction in transportation of goods and services points towards the efficiency and dynamic transition through available transport system. North Eastern Corridor of Taiwan (NECT) is one of the clear examples of efficiency in trade in terms of terminal operation cost, traffic accident cost and transit time between two points [16].

Similarly, a strongly significant $(\mathrm{P}=0.000)$ association was found between the CPEC project and improvement in travelling potential, but a highly significant $(\mathrm{P}=0.000)$ association was found between $\mathrm{CPEC}$ and the reduction in the cost of travelling and the barrier of travelling transport. There is perhaps no other option left behind for further transport chain realization. Furthermore, $\mathrm{CPEC}$ as a project would cater for the need requirements of these two countries. Along with the development of transport routes through CPEC, the reduction will occur in traffic and traffic accidents. It discloses the fact that CPEC contains all the state of the functionary dynamics regarding the transportation. Likewise, a significant $(\mathrm{P}=0.000)$ association was found between the development of transport infrastructures through CPEC and fastness and reliability in business travelling. It has been deduced from these findings that with the development of transport infrastructure in the form of the road from the Karakorum to Islamabad (KKHW) and the railway track from Peshawar to Karachi will bring fastness, 
ROMANIAN JOURNAL

OF TRANSPORT INFRASTRUCTURE

Ashfaq U. Rehman, Azizul Hakim, Khalid Khan, Ihsan Ullah Khan

Role of CPEC in development of trade, transport and economy of Pakistan

reliability and ensure efficiency in all aspects of trade and transport. These findings are in resemblance to the view of Calderon [9] that improvement in infrastructure increases reliability in delivering and manufacturing of goods.

Likewise, a strongly significant association $(\mathrm{P}=0.000)$ was explored between the development of transport infrastructure through CPEC and improvement in labour force productivity. It has been deduced from these results that infrastructure development has positive impacts on the production of almost skilful labour participation and leading to quality products available on the market. It will influence their work in terms of production and in terms of quality. These results quantitatively support the findings of Suh [23] that $10 \%$ improvement in transport infrastructure will increase $8 \%$ of industrial products. A strong and significant $(\mathrm{P}=0.000)$ association was found between CPEC and improvement in the geographical size of the labour market. On the other hand, a strongly significant $(\mathrm{P}=0.000)$ association was found between the development of transport routes and improvement in the range of choice of individual and firm. Availability of choice and subsequent selection for people according to the needs and requirements borrow them economic strength. It could be one of the attractive and salient features of CPEC to the locals. It would lead to more participation of all segments of business activities, representing all class participation right, poor, middle and rich.

\section{CONCLUSION}

In a nutshell, CPEC will ensure efficiency in terms of development in trade and transport thus improving the economy. Development of transport infrastructures increases frequently travelling potential of goods. This could come true as CPEC would ensure smooth and efficient transportation, reducing time, distance and cost. In addition, it leads to maximum involvement of local people as labours having access to the job market with a high rate of social mobility, ultra-geographical constraints and some low accessibility. It is suggested that CPEC should not be politicized; rather efforts should be made to accommodate all stakeholders to get maximum benefits, outfits through political leaders in the driving seats. It must be ensured that all parts of Pakistan be included in the activities pertaining to CPEC. It would dispel the impression of marginalization by the smaller and less developed provinces. Nonetheless, active participation of all stakeholders will contribute in the successful implementation of the all the targeted projects. Ownership by all stakeholders along with the introduction of key governance reforms will strengthen the economy of the region in general and particularly of Pakistan. 


\section{ROMANIAN JOURNAL OF TRANSPORT INFRASTRUCTURE}

\section{REFERENCES}

[1]. PAKISTAN TODAY, "The Sino-Pakistani Partnership" by Ahmed Rashid, retrieved from:https://www.pakistantoday.com.pk/2013/07/05/the-sino-pakistani-partnership2/, published on July 5,2013.

[2]. W. I. GHANI, R. SHARMA, "China Pakistan Economic Corridor Agreement: Impact of Shareholders of Pakistani Firms". International Journal of Economics and Finance 10(1): 148, 2017.

[3]. CHINA DAILY, "Economic Corridor links China, Pakistan Dreams". retrieved from :http://usa.chinadaily.com.cn/business/2014- 6/28/\%20content_1762184\%208.htm, published on September 13, 2013.

[4]. EXPRESS TRIBUNE, "Foreigners: Special Desks Set-up to Provide Security to Chinese Citizens". Retrieved from:http://tribune.com.pk/story/722021/ foreignersspecial-desks-set-up-to-provide-security-to-chinesecitizens, published on June 15,2014 .

[5]. PAKISTAN OBSERVER, “CPEC and India's Growing Nervousness”. Retrieved from:https://pakobserver.net/cpec-and-indias-growing-nervousness-2/,published on March 22,2018.

[6]. PAKISTAN TODAY, "Pakistan, China to Collaborate in 21,690 MW Projects under CPEC." $\quad$ Retrieved from: https://www.pakistantoday.com.pk/2014/04/15/business/pakistan-china-tocollaborate-in-21690-mwprojects-under-cpec >Pakistan, published on April 15,2014.

[7]. M. D. MEYER, E. J. MILLER, "Urban Transportation Planning: A Decision Oriented Approach". McGraw-Hill, New York, 1984.

[8]. D. DEWAR, "The Urban Question in South Africa: The Need for a Planning Paradigm Shift. Third World Planning Review 17(4): 407-419, 1995.

[9]. C. CALDERON, L. SERVEN, "The Effect of Infrastructure Development on Growth and Income Distribution" World Bank Publications (Policy Research Working Paper No. 270),2004.

[10]. J. F. ARVIS, G. RABALLAND, J. F. MARTEAU, "The Cost of Being Landlocked: Logistic Cost and Supply Chain Reliability", World Bank Publications (Policy Research Working Paper No. 4258), 2007.

[11]. D.NJINKEU, J. S. WILSON, B. P. FOSSO, "Expanding Trade within Africa: The Impact of Trade Facilitation". World Bank Publications (Policy Research Working Paper No. 4790), 2008. 


\section{ROMANIAN JOURNAL OF TRANSPORT INFRASTRUCTURE}

[12]. V. AHMAD, S. GHULAM, "Trade Facilitation for Economic Corridors in South Asia: The Perspective of Pakistan”. University Library of Munich, Germany, 2011.

[13]. H. D. BROOKS, J. MENON, "Infrastructure, and Trade Cost in Asia", A joint publication of Asian Development Bank Institute and Edward Elgar Publishing, 2008.

[14]. B. BOSWORTH, S. M. COLLINS, "Accounting for Growth: Comparing China and India”. Journal of Economic Perspectives 22(1): 45-66, 2008.

[15]. S. L. LIU, A. G. HU, "Transport Infrastructure and Economic Growth: Perspective from China's Regional Disparities [J]”. China Industrial Economics 4: 14-23, 2010.

[16]. D. KOLSCH, P. SALING, A. KICHERER, A. GROSSE-SOMMER, I. SCHMIDT, "How to Measure Social Impacts? A Socio-eco-efficiency Analysis by the SEEBALANCE® Method." International Journal of Sustainable Development 11(1): $1-23,2008$.

[17]. B. P.LOO, C. CHEN, E. T. CHAN, "Rail-based Transit-oriented Development: Lessons from New York City and Hong Kong." Landscape and Urban Planning 97(3): 202-212, 2010.

[18]. F. PAGLIARA, E. PAPA, "Urban Rail System Investments: An Analysis of the Impacts on Property Values and Residents' Location". Journal of Transport Geography 19(2): 200-211, 2011.

[19]. B. SU, A. HESHMATI, Y. GENG, X. YU, "A Review of the Circular Economy in China: Moving from Rhetoric to Implementation", Journal of Cleaner Production 42(3): 215-27, 2013.

[20]. U. SEKARAN, “Research Methods for Bussiness: A Skill Building Approach”. USA: Hermitage Publishing Services (4th Ed.) 2003.

[21]. J. T. CROASMUN, L. OSTROM, "Using Likert-Type Scales in Social Sciences". Journal of Adult Education 40(1): 19-22, 2011.

[22]. N. W. ISMAIL, J. M. MAHYIDEEN, "The Impact of Infrastructure on Trade and Economic Growth in Selected Economies in Asia". ADBI Working Paper No. 553. Retrieved from: https://papers.ssrn.com/sol3/papers.cfm?abstract_id=2709294, 2015.

[23]. T.SUH, J. O. KHAN, "The Effect of FDI Inflows and ICT Infrastructure on Exporting in ASEAN/AFTA Countries: A Comparison with other Regional Blocs in Emerging Markets". International Marketing Review, 20(5), 554-571, 2003. 